\title{
Influence of Volunteer Leaders' Competence on Church Performance: Evidence from the Presbyterian Church of East Africa Nakuru East Presbytery, Kenya
}

\author{
Pauline Kanuthu Mwaura ${ }^{1}$, Dr. Maina Waiganjo ${ }^{2}$, Dr. Njenga Gitahi ${ }^{2 *}$ \\ ${ }^{I}$ Master of Science in Organization Development (Human Resource Option) of Kabarak University \\ ${ }^{2}$ School of Business and Economics, Kabarak University, Kenya
}

*Corresponding Author: Dr. Njenga Gitahi, School of Business and Economics, Kabarak University, Kenya

\begin{abstract}
Volunteer leaders' competence is emerging as one of the changes that both profit and non-profit organizations have to accommodate especially as more people look for opportunities to serve, learn, gain new organization experiences and derive personal fulfillment. The success or failure of any profit or non-profit organization largely depends on the efficiency of its human capital. Most non-profit organizations including churches depend on volunteer workers to take the position of leadership and management because of their limited resources. In this regard, this research aimed at assessing the influence of volunteer leader's competence on church performance. The study sought to determine the influence of volunteer leaders' commitment, emotional intelligence, personal attributes and leadership styles on church performance. The general objective of this study was to access the influence of volunteer leaders' competence on church performance: evidence from the Presbyterian Church of East Africa Nakuru East Presbytery, Kenya and was anchored on the Social Exchange Theory of Volunteerism and the Contingency Theory of Leadership that try to show how church performance relates to volunteer leaders' competence. This study adopted a descriptive survey research design and the design was deemed appropriate to the study because the research was seeking to establish a cause-effect relationship between volunteer leaders' competence and church performance. The target population of the study was 750 church leaders composed of 288 Church Elders and 462 Group Leaders. Nassiuma formula was used to obtain a sample size of 88 respondents after which Neyman allocation formula was used to proportionally allocate the sample size across the categories of the respondents giving a sample size of 33 elders and 55 group leaders. Volunteer leaders in all the eleven parishes were randomly selected. Primary data was collected using a questionnaire which was pretested to ensure content validity and also reliability at the recommended Cronbach alpha of 0.7. Collected data was analyzed using both descriptive and inferential statistics with the help of the Statistical Package for Social Science (SPSS). Multiple linear regression was used to determine the relative effectives of the volunteer leaders' competence on church performance. Findings were presented in graphs and tables. The study revealed significant influence of volunteer leaders' commitment $(t=4.356, p=0.00)$, emotional intelligence $(t=3.012, p=0.003)$, personal attributes $(t=4.654, p=0.00)$ and leadership styles $(t=4.654, p=0.00)$ on performance of PCEA Nakuru East Presbytery. The study concluded that volunteer leaders' commitment, emotional intelligence, personal attributes and leadership styles contributed to a large extent to church performance. The researcher recommends that the church should acknowledge the great role volunteer leaders play and come up with strategies to motivate and inspire them so that they can continue volunteering and also increase their effectiveness and performance. The researcher further recommends that a study be undertaken on the strategies to enhance volunteer leaders' competence to increase church performance.
\end{abstract}

Keywords: Commitment, Emotional Intelligence, Personal Attributes, Leadership Styles and Church Performance.

\section{INTRODUCTION}

Today's organizations whether for profit or non-profit are under increasing pressure from their competitors and stakeholders to perform. Competitive pressures manifest in many forms from rivalry, regulations, standards and subscriber choice, for example, demand that the modern organization constantly assess its position, resources, management, leadership and competencies among other things. As a result, organizations experience continuous change in the way they are managed and the way they operate (Parvin\&Kabir, 2011). 
The concern of managers at different levels in organizations centers on their effectiveness under a constantly changing environment. Organizations grow and become efficient in operation by adopting and pursuing best practices in the context of change (Khan, Mahmood, Kanwal, \&Latif, 2015). Volunteerism is emerging as one of the changes that both profit and non-profit organizations have to accommodate especially as more people seek opportunities for experience and deriving personal fulfillment (Thomas, Selvadurai, Lyndon, \&Moorthy, 2011).

\subsection{Global Perspective of Volunteer Leaders' Competence}

The value of volunteerism to the organization has been underscored in literature with conservative figures in the US. For instance, the United States Bureau of Labor Statistics (2014) estimated volunteers to be approximately 62.6 million people between September 2012 and September 2013.Estimates on economic impact place the value of volunteer work at $\$ 1.348$ trillion or 2.4 per cent of the entire global economy. The contribution of volunteers' time from 63.4 million people are estimated to have donated 8.1 billion hours of service annually, which equates to $\$ 173$ billion economically and by extension contribute significantly to organizational performance (Choi \&DiNitto, 2012). According to Vecina, Chacon, Marzana, and Marta (2013), these figures confirm that volunteerism has become a crucial element for many organizations globally, especially non-profit services-focused organizations. In addition, non-profit organizations are integral components of the Australian society, with an annual turnover of approximately $\$ 100$ billion. Non-profit organizations in Australia are estimated to be 700,000 many of which rely on volunteers to deliver social services in key sectors of development.

The most common types of volunteer organizations are in the areas of sports/physical recreation, education/training, community/welfare and religion across every state of Australia (Australia, 2015). Moreover, in Australia McFadden and Smeaton (2017) studied the volunteer experiences through a phenomenographic research approach. The study examined students involved in interdisciplinary volunteer program within the community. The findings of this study showed that volunteers experience a range of authentic learning to a more amplified experience.

In a study in Columbia, Brunette (2011) examined the acts of volunteering with regard to motives, outcomes, attitudes and commitment of the volunteers using a functional approach. The study found that volunteers were not influenced by the organizational intent but remained highly ambitious to continue as volunteers. A study by Balduck, Van Rossem and Buelens (2010) also explored the competencies of volunteer board members of a non-profit organization in the United Kingdom and concluded that there was need for the board members to have the necessary competencies which include the personal traits, social role, knowledge and skills which results in impacting the overall performance of the organization. In addition, the study also found that there was a positive impact of effective commitment to performance.

\subsection{Regional Perspective of Volunteer Leaders' Competence}

In the African region, volunteers are increasingly being relied upon to provide some essential services for people, especially within the South Africa context. This presents several unique challenges which are specifically related to Africa. A study by Perold et al.(2013) which explored volunteering in Africa also acknowledged that in the context of high unemployment, volunteers may view volunteering as a stepping stone to employment, although it remains unclear what motivates people to volunteer their services in their different communities.

Secondly, a study by Ghoneim and Baradei (2013) examined the relationship between strategic planning and organization performance among the non-profit organizations in Egypt. The study also assessed the growth and development of volunteers as a strategy to enhance performance of the nonprofit organizations and concluded that volunteers' competence results in superior performance among organizations.

In addition, in Ghana Afari-Asiedu et al. (2018) examined the factors which influence motivation for the retention of community based volunteers within the health sector. Using cross-sectional survey, the study found that community based volunteers were motivated by their personal interest. In Nigeria, Tobin-West (2015) also examined the effectiveness of trained volunteers through a quasiexperiment. The study found that adequate knowledge improved effectiveness of volunteers. 


\subsection{Local Perspective of Volunteer Leaders' Competence}

Coming back to Kenya, communities have always voluntarily organized themselves, as part of their traditions and culture through formal and informal structures to help each other in times of need and in times of celebration. A study by Lewis (2015) on volunteerism in Kenya identified volunteering as something considered to be a low skilled and low-paying activity. As a result, most volunteers are the unemployed people (who are also often youth) hoping to get experience for employment opportunities and derive personal fulfillment. In some cases, the very poor volunteer with the hope of receiving some form of basic allowances or food. As indicated above, volunteering should not only be for the unemployed but most people tend to withdraw their volunteer services once they have gained employment. However, some withdraw their services as a result of professional pressure which limits their time.

Some of those who have previously relied on volunteering as a stepping stone to employment hold the opinion that returning to volunteering is moving backwards and they consider it to be working for less than they are worth. Despite the reduced numbers of people volunteering, there are still some people who continue to volunteer throughout their lives and typically consider it to be a calling. A study by Muriithi (2014) to determine the factors that influence the sustainability of the non-profit organizations in Kenya noted that competence was one of the factors. Competence was found to be significant for the productivity of the volunteers. The other factors that affected the non-profit organizations included its policies.

\subsection{Volunteer Leaders' Competence}

Based on the observations highlighted above, there is need for community support and involvement in the design and implementation of policies formulated to address local problems, and this is vital for the spirit of volunteerism (Kiangura \&Nyambegera, 2012). According to Wilson (2012) volunteering refers to activities whereby time is given freely to benefit another person, group or organization.Volunteers are employed individuals who give time during a planned activity for a nonprofit or charitable organization, the church being one of those organizations (Rodell, Breitsohl, Schroder, \& Keating, 2016).

Peklaj (2015) defined competence as an observable and measurable behavior that has a definite beginning and ending. That competence can be performed within a limited amount of time, consists of two or more competence builders, and leads to a product, service, or decision. He further defined a competence builder as "the skills, knowledge, and attitudes needed to perform a given competence".

In addition, Seemiller (2016) defined competence as a set of behaviors instrumental in the execution of a task to achieve the desired results or outcomes. The competencies of a leader include personal traits, skills, behaviors, values and knowledge that contribute to superior performance. Therefore, competence refers to the knowledge, skills and values required for performing a task. In order for leadership to perform effectively, competence represent an attempt to capture the experience, lessons learned and knowledge of seasoned leaders to provide a guiding framework for the benefit of others and the organization.

Consequently, this study defines volunteer leaders' competence as observable and measurable behaviors, personal traits, skills, values, experience and knowledge of volunteer leaders that contribute to superior church performance. In addition, although there are other aspects of competence that may have been considered, commitment, emotional intelligence, personal attributes and leadership styles align perfectly to the competencies highlighted in a faith based organization with regard to its needs as it relies on volunteer leadership. Thus, these four factors will be used to formulate the independent variables of this study.

\subsection{Church Performance}

According to Hurduzeu (2015) organizational performance refers to how well an organization achieves its market-oriented goals as well as its financial goals. This concept includes the effective utilization of all resources at the disposal of the organization for profit maximization and future growth of the organization.For any organization, performance is a recurrent theme of strategic management and it is of interest to both academic scholars and practicing managers (Obiwuru, Okwu, 
Akpa, \&Nwankwere, 2011). An organization's performance is based on the measure of standard or prescribed indicators of effectiveness, efficiency and environmental responsibilities such as cycle time, productivity, waste reduction and regulatory compliance (Bukirwa\&Kising'u, 2017). Thus, church performance refers to how well the church utilizes all resources at its disposal to achieve its spiritual and social goals as well as its financial goals.

According to Coleman (2017) church performance is based on the church attendance, growth, programs, and projects that it is undertaking. For him, organization performance of the church is important given that the church is one of the inter-societal components that provide society with blueprints. However, there are people who believe that the church should not be supplying society with blueprints and for them the church should stay away from political, social, economic and judicial issues. There is a belief that this would place Christian faith and the mission of the church at risk (Bukirwa\&Kising'u, 2017). Essentially, the church's mission first and foremost is to provide spiritual nourishment to their members and the community at large, then where possible they provide interventions to local communities through carefully designed projects meant to empower them such as schools, vocational training institutions, recreation activities, health and water. This obviously entails a lot of decision making at different levels so as to ensure that the available resources are utilized in such a way as to ensure maximum effectiveness (Bell, Masoka, \& Zimmerman, 2010).

As such, the church requires highly skilled employees and competent volunteer leaders to deliver their services competitively to continually gain the support of the community and their partners. To enhance performance on growth, ability to meet its financial obligation and expand attendance, competent volunteer leaders are needed in the church. However, attracting and retaining such staff especially in the present day and age still remains the institutions greatest challenge notably due to the attitudes potential candidates have towards church work (Vick, 2011).

\subsection{Presbyterian Church of East Africa}

The Presbyterian Church of East Africa (PCEA) was established in 1891 when the first missionary team from Scotland came to Kibwezi, Kenya. Later, the locality was found to be unfavorable and hence the mission work was relocated to Thogoto, Kikuyu in 1898 which became the point of further missionary work in the country. PCEA today covers Kenya, Tanzania and Uganda. The church has 56 Presbyteries and over 400 Parishes, over 1,000 Congregations and thousands of Elder Districts. Presbyteries and parishes are both administrative and ministry areas. The PCEA church has a practice and procedure manual that contains all the policies that guide its operations. The church has only two ordained offices, that is the ministers and the elders. The office of an elder is so integral to the church that even the ministers start off by being ordained as elders. Indeed, the very title 'elder' is the English equivalent of the Greek word 'presbuteros' the root word from which the church derives its name (Thegu, 2018).

The Presbyterian church is therefore a church that is governed by elders through various church courts, namely, the Kirk Session, Presbytery and General Assembly. Elders are elected from members of a congregation and are ordained for life though they have a retirement age. The minimum required age for one to be ordained as a church elder is 25 years of age while one retires after attaining 65 years of age. Elders in the active eldership position (active elders) are those that have not yet retired. Unlike the ministers, elders volunteer their services to the church. The Church encourages individuals who feel called by God to volunteer themselves for appointment or election to such offices. Outside of the courts of the church, PCEA also has Standing Committees manned basically by lay (non-ordained) members. These 'lay leaders' are the ones referred in this study as 'Group Leaders' who also volunteer their services to the church (PCEA, 1998). Thus, the office of eldership is a voluntary office and does not attract any monetary emolument as well as that of the group leaders. The PCEA church is governed by volunteer leaders making it an information rich study area. Nakuru East Presbytery is one of the 56 presbyteries and it has 11 parishes and 77 congregations and the presbytery is large compared to other presbyteries in Nakuru County. The Presbytery has 288 active elders and 464 parish group leaders.

\section{Statement of the Problem}

Faith-based organizations play a critical role in the society besides providing spiritual care to the adherents because they also provide services in areas where the government is not involved. However, 
over the last three decades the church as a non-profit organization has been evolving considerably from the traditional model that focused only on spirituality. Today's church is inclining towards organizational characteristics similar to other non-religious organizations; however, it is operating and managing staff in an environment of scarce resources. Church organizations, like many other organizations, face serious challenges of managing their operations and resources at their disposal due to lack of expertise and insufficient personnel (Kabetu\&Iravo, 2018). They therefore seek the involvement of volunteers to bridge the human capital gap (Chigozie, Munene, \&Gakuo, 2017).

Many individual volunteers commit themselves to church organizations to handle a variety of responsibilities ranging from leadership to technical which require the right skills, knowledge and behaviors. However, volunteers also have personal needs and obligations and they therefore try to strike a balance between the two concerns and it's common to find some focusing on occupations that are profitable (Gorgens\&Kusek, 2010).

Church performance can be achieved through focusing on leadership competence.Few studies have examined volunteer leader's competence especially for the non-profit organizations such as a research study conducted by Kabetu and Iravo (2018) which examined the influence of strategic leadership on performance of foreign NGOs in Kenya. Although competence of staff in the non-profit organization was an objective, it was not the main focus of the study. In addition, a study by Gorgens and Kusek (2010) argued that there is need to understand the skills needed and the capacity of volunteers by undertaking a human capacity assessment before enrolling them in a business organization. A study by Ndonye (2019) also investigated the impact of leadership approaches on church growth but did not look at the competence of volunteer leaders. Lack of literature focusing on the volunteer leader's competence was the motivation behind this study. Therefore, the study aimed at bridging this gap by investigating the influence of volunteer church leaders' competence on non-profit organizations with a special focus on the PCEA church performance in Nakuru East Presbytery.

\section{OBJECTIVES OF THE STUDY}

- To establish the influence of volunteer leaders' commitment on performance of PCEA Nakuru East Presbytery.

- To assess the influence of volunteer leaders' emotional intelligence on performance of PCEA Nakuru East Presbytery.

- To determine the influence of volunteer leaders' personal attributes on performance of PCEA Nakuru East Presbytery.

- To analyze the influence of volunteer leaders' leadership styles on performance of PCEA Nakuru East Presbytery.

\section{RESEARCH HYPOTHESES}

$\mathbf{H 0}_{1}$ : There is no significant influence of volunteer church leaders' commitment on performance of PCEA Nakuru East Presbytery.

$\mathbf{H O}_{2}$ : There is no significant influence of volunteer church leaders' emotional intelligence on performance of PCEA Nakuru East Presbytery.

$\mathbf{H 0}_{3}$ : There is no significant influence of volunteer church leaders' personal attributes on performance of PCEA Nakuru East Presbytery.

$\mathrm{HO}_{4}$ : There is no significant influence of volunteer church leaders' leadership styles on performance of PCEA Nakuru East Presbytery.

\section{LITERATURE REVIEW}

\subsection{Social Exchange Theory of Volunteerism}

Social exchange theory dates back to 1901 when Chavannes (1901) defined it as a "fundamental explanation of all human relationships as it encompasses all aspects of relations between human beings". According to Blau (1964) social exchanges are "voluntary actions of individuals that are motivated by the returns they are expected to bring and typically do in fact bring from others". Thus, social exchange theory is an exchange relationship based on shared understanding and the norm of 
reciprocity. The exchange can be in the form of discussion, favors, assistance, money, love, goods or services. However, Blau argues that the norm of reciprocity reinforces and stabilizes the existential conditions of the exchange itself and is not the central driving force of exchange. In other words, individual motives or desires play a major role in how a relationship is initiated and how it can be sustained.

The relationships between volunteers and staff in non-profit organizations are founded on the social exchange theory. The theory is based on the premise that social interactions are combinations of economics and behavior (Smith, Hamon, Ingoldsby, \& Miller, 2012). Blau (1994) asserted the basic assumption of the theory to be that people enter social relations because they expect intrinsic or extrinsic rewards. The desire to satisfy some want or need is assumed to underlie the association, with the voluntary social action ceasing when expected reactions are not forthcoming. Thus, volunteers and staff would be expected to remain in their roles as long as they perceive their self-interests to be satisfied, and that the benefits are equitable to what others are perceived to receive. In addition, people engage in relationships according to their perceptions of cost and benefits.

Consequently, social exchange theory suggests that make voluntary people contributions based on perception that they are being rewarded.This implies that an individual who perceives an imbalance between contributions and rewards is likely to move toward a greater equilibrium. In that sense, a volunteer who perceives that the rewards for volunteering are imbalanced with contributions is likely to discontinue involvement. Accordingly, fulfilling the obligation of repaying what has been received is central to social exchange, and as long as the exchange is balanced regarding frequency and value, the relationship will continue to grow.

The social exchange theory was relevant to the study because it provided an understanding of why volunteers offering services to non-profit organizations might consider time spent as a form of cost exchanged. Therefore, volunteers may volunteer without expecting monetary compensation but expecting social rewards such as personal attraction, social acceptance, social approval, instrumental services, respect, prestige, compliance and power. Reward can also take the form of learning, gratitude, perceived higher status associated with giving back to the community, and an overall sense of self-fulfillment (Hinck, 2000). Thus, this theory gives meaning to the variable on commitment showing why a volunteer may be involved or may discontinue involvement in the organization.

According to Blau (1964), trust, loyalty and commitment are the basis for social exchange relationships and are bound to emerge under conditions of continuous exchange, resulting in longterm relationships. Trust is regarded as a social currency, and its required in a social exchange relationship to sustain relationships in both negotiated and non-negotiated exchanges, although its required more in non-negotiated exchanges, especially as it applies to the relationships between volunteers and their supervisors and organizations. However, trust is broken when expectations are not met by any of the organizations' agents. As a result, volunteers will be affected psychologically in their social exchange and this will affect satisfaction which in turn affects attitudes and behaviors, including the level of commitment, turnover, citizenship behaviors and intention to stay (Bang, Won, \& Kim 2009).

\subsection{Contingency Theory of Leadership}

The Contingency Theory of Leadership was proposed by Frederick Fielder in 1964 (Miner, 2015). The contingency theory emphasizes the importance of both the leader's personality and the situation in which that leader operates. Fielder observed that effective leadership styles depended on situational contingencies such as the nature of the task and how certain or uncertain it was (Sajjadi, Karimkhani, \&Mehrpour, 2014).

According to the contingency theory, leadership depends on four contingent factors namely; the leader's power and influence and his or her chosen goals, followers' expectations, the complexity of the organization, and the certainty or uncertainty of the task (Lorsch, 2010).Krigerand Seng (2005) also examined the contingency theory from a religious perspective and they concluded that effectiveness of leadership can also be contingent upon the inner value of the leaders and their respective religions. According to the contingency theory, what may work for a leader in one situation may not work in another situation. Change in a situation may result to failure for a leader who was successful in another situation. 
In volunteer leadership, there are no incentives to motivate leaders to perform compared to what takes place in profit organizations. Therefore, the theory implies that the motivation and ability of a leader affects their decision in a given situation. In this theory, then, how one leads depend heavily on the followers' abilities and attitudes not just on the leaders' abilities and attitudes. The contingency leadership theory applies well to the present study since it will give meaningful insight into the key variables of the study, that is, emotional intelligence, personal attributes and leadership styles. The theory suggests that effective leaders have the ability to work with others and also build a cohesive and balanced team capable of creating a structure within which activities can be accomplished.

\subsection{Volunteer Leaders' Commitment and Church Performance}

Nguyen (2014) notes that commitment-based service organizations hold the view that commitment of employees contributes to the stability of the workforce and this provides better customer service and increases organizational performance.As a result, committed employees are increasingly becoming important assets for organizations.In the volunteering field, organizational commitment, satisfaction, and intention to re-main are classic and related concepts (Vecinaet al., 2013). Organization factors such as organizational dependability, effectiveness of the organization's social processes and organizational climate strengthen employee commitment (Adenike, 2011).

Commitment has been defined as a psychological state that binds the individual to the organization (Meyer \& Maltin, 2010). This binding can be experienced in three different ways. The first is affective commitment, which refers to the extent to which an employee becomes emotionally attached to, identifies with, believes in and becomes involved in the organization. A high level of affective commitment results in low employee turnover, low absenteeism and improved job performance hence employees with a strong affective commitment continue employment with the organization because they want to do so (Wang, Indridason, \& Saunders, 2010). The second is continuance commitment which is defined as continuing with the organization due to the associated cost of leaving or the perceived cost of leaving. It refers to the extent to which employees feel committed to the organization based on years of service. Employees whose primary link to the organization is based on continuance commitment remain because they need to do so (Loi\& Foley, 2008). The third mindset is normative commitment, which reflects an employee's feeling of obligation to remain in the organization because it is the right thing to do. The employee believes that it is morally right to be loyal and stay in the organization (Coyle-Shapiro, 2008). Affective commitment is considered to be the most important type of organizational commitment among volunteers.

Organizational commitment has also been defined as a strong emotional identification with a concrete organization, manifested by a belief and acceptance of its goals and values, a willingness to make efforts for the organization, and a desire to continue as a member (Meyer, Stanley, Herscovitch, \&Topolnytsky, 2002). According to Luthans and Fred (2006) organizational commitment is an attitude that shows the loyalty of employees and is considered as a continuous process of how the members of the organization express their interest on the success and the good of the organization.

Members who have high commitment have a strong involvement in the organization and also stay in the organization for longer than those who are less committed (Scott, 2007). In addition, commitment involves generating human energy and activating the human mind without which the implementation of new ideas and initiatives will be compromised (Ajibade\&Ayinla, 2014).

In today's competitive world, profit and non-profit organizations cannot perform at peak levels unless each employee is committed to the organization's objectives and works as an effective team member. For the purpose of this study, volunteer leaders' commitment is viewed as commitment to the church as well as leaders' commitment to their responsibilities. It applies to the dedication a volunteer leader has to the church (Donahue \&Robinson, 2009) which is indicated through the strong desire of the volunteer to stay as an organizational member, the desire to exert efforts for the sake of the organization as well as the belief and strong acceptance of the aims and values of the organization (Luthans\& Fred, 2006).

\subsection{Volunteer Leaders' Emotional Intelligence and Church Performance}

Leadership plays a vital role to motivate employees and attain organizational goals. Researchers argue that emotional intelligence (EI) is a critically important competence for effective leadership and team 
performance in organizations. Additionally, Goleman (2011) linked managing emotions with effective leadership in business and validated that it's the basic component for distinguishing between great and average leaders, thus, EI is key to successful leadership. No matter what leaders set out to do, their success depends on how they do it and this calls for EI. Goleman defines EI as the capacity for recognizing our own feelings and those of others, for motivating ourselves, and for managing emotions well and in relationships.

The ability to understand and control one's own emotions and those of others varies from person to person and those with a higher ability are known as emotionally intelligent. An emotionally intelligent volunteer has personal competence (how we manage ourselves) and social competence (how we manage relationships) skills. Leaders who manage their emotions effectively and address their followers concerns with greater proficiency, establish more caring interpersonal relations (Humphrey, 2012).It is important to note that an organization consists of human beings and when people are involved, emotions automatically come into play, and a church is no different.It would be unwise to assume that a church is all objective, no-emotion only performance kind of a packed room where hormones have no scope to creep in. However, the fact is that emotions alone are the biggest motivator or de-motivator of a worker. Emotions govern the performance and efficiency of a worker and had it not been the case, we would have never talked about the importance of work-life balance (Kurtessis et al., 2017).

Goleman (2011) categorized EI into four key categories: Self- Awareness (knowing how we feel in the moment and using our feelings to drive decision making), Self- Management (handling our own emotions so that they don't interfere but facilitate decision making), Social Awareness (ability to understand situations from others perspective) and Social Skills which is also referred to as Relationship Management (ability to influence, persuade, negotiate, lead and manage conflict). A study by Asilaza (2016) on the effect of emotional intelligence on employee performance in Kenya concluded that well developed management skills of the four domains of emotional intelligence; selfawareness, self-management, social-awareness and social skills enable employees to understand and manage their abilities and control short comings in a better and mature manner as they interact with others and manage their social networks for the purpose of achieving greater performance.

\subsection{Volunteer Leaders' Personal Attributes and Church Performance}

Early research on personal attributes believed that personal traits were related to effective leadership. The majority of the empirical work focused on the systematic investigation of the leaders and their followers (Marinelli-Poole, McGilvray, \&Lynes, 2011)). In the church context, leadership trait is important because leaders are assumed to behave according to the teaching of the church. Church leaders are individuals from diverse backgrounds and experiences making them a unique team of volunteers. Leaders are people who are reasonably expected do the right things (Zaccaro, 2007). At the head of the group is the leader who is equally as important as its followers, but can make or break the group.The basic role of a leader is to foster mutual respect and build a team where each individual's strength is utilized for maximum productivity. Therefore, a leader provides direction by developing a vision for the future and aligns people by communicating this vision and inspiring them to overcome hurdles.Management involves implementation of the vision and strategy provided by leaders, coordination and staffing the organization as well as handling day-to-day activities (MacDonald, Sulsky, \& Brown, 2008). According to Marinelli-Poole et. al. (2011) leadership is about how to behave, communicate and manage others. Effective leaders have certain traits and attributes that influence their relationship with others.

Leadership attributes are inner or personal qualities that contribute to effective leadership. These attributes include characteristics such as values, character, motives, habits, traits, style, behaviour, and skills (Virkus, 2009). While notion of the natural-born leader exists, research suggests that only onethird of leadership traits are genetic. Most leadership skills are learned gradually through life experiences and one can accelerate that learning curve by implementing volunteer leadership development (Parr, Lanza, \&Bernthal, 2016). A trait such as the ability to influence others to get things done is common among effective leaders.

In addition, there are leaders with ability to see the big picture which helps them to rise above the daily routine to see things in a broader perspective. This attribute of a leader helps others to get out of 
their comfort zones or cocoons to take more risks and achieve more (Dinhet al., 2014). While exploring volunteers in Kelloway, Turner, Barling, and Loughlin (2012) found that effective leaders are gifted teachers because they want others to develop. This attribute of a leader results in helping others to be credible and provide growth opportunities. Coaching others to develop and delegating responsibility is characteristic of leaders with teacher and mentor traits. These are leaders who do not feel threatened by others and take pleasure in the success of others.

Secondly, level of education is the most consistent predictor of volunteering. Education is a significant attribute in leadership because it provides a leader with knowhow and ability to search for appropriate information (Ng. \& Feldman, 2009) as well as boost volunteering because it heightens awareness of problems, increases empathy, and builds self-confidence. Educated people are also more likely to be asked to volunteer. They therefore belong to more organizations where they develop more civic skills, such as the ability to run a meeting. Nevertheless, the importance of education varies by type of volunteer work and also increases if the task assigned requires literacy skills as opposed to social skills (Wilson, 2012).

In addition, the training of a leader is also an important tool for the organizational growth and success. According to Elnaga and Imran (2013) training refers to bridging the gap between the current performance and the standard desired performance. Training of volunteers is essential as it motivates and inspires workers by providing them with all the information they need to perform the assigned tasks and this makes them more efficient. Thus, the education and training of volunteer leaders is beneficial not only to them but also to the church.

Moreover, work experience determines performance of an organization. According to Prasetya (2018) work experience is the time spent by a person to acquire knowledge, skills and attitudes in accordance with the tasks assigned to him. Nafishah (2013) also states that work experience is the length of a person carrying out the frequency and types of duty according to his ability. Consequently, a volunteer leader's work experience is time spent by the volunteer to acquire knowledge, skills and attitudes in accordance with the frequency and the type of task. Organizations tend to choose experienced workers than the inexperience. When it comes to execution of work, an experienced worker's implementation of work goes smoothly because the person already has some knowledge, skills and attitudes (Prasetya, 2018). Thus, the volunteer leaders' work experience has an invaluable contribution to church performance.

\subsection{Volunteer Leaders' Leadership Styles and Church Performance}

Leadership styles have significant impact on organizational performance. Choudhary, Akhtar and Zaheer (2013) defined leadership style as actual leadership behavior and actions toward followers as opposed to innate qualities which a person might possess. Klein, Wallis and Cooke (2013) conducted a research on the impact of leadership styles on organizational culture and firm effectiveness. They concluded that leadership styles influence the culture of an organization and consequently influence organizational performance. According to Gotsis and Grimani (2016) leadership is the art of influencing and inspiring subordinates to perform their duties willingly, competently and enthusiastically for the achievement of group objectives. This study will look at the two categories of leadership which are commonly practiced and have an impact on church performance, that is, transactional and transformational leadership styles.

Transactional leadership style is identified through task clarification and exchanges between leader and follower through rewards or punishments based on behavior (Choudharyet. al., 2013). According to Uchenwamgbe (2013) a transactional leader is always willing to give something in return, for example, promotion, pay rise and new responsibilities. Hashim, (2014) examined the impact of volunteer transactional leadership style on the employees' job satisfaction in Pakistan. The study found that the transactional leadership style had positive relationship on the employees' job satisfaction. Rewards and benefits have a big impact on the employees' performances and job satisfaction because these factors influence the workers to work hard and be positive at the end of the day.

Additionally, a study by Uchenwamgbe (2013) revealed that transactional leadership style has a positive impact on the organizational performance since it helps in creating as well as sustaining the context in which organizational and human capabilities are maximized as the employees are always able to achieve the tangible and intangible rewards. The transactional leadership style articulates the 
compelling vision that enhances the overall organizational performance as well as creates an ideal environment for performance. However, this type of leadership does not have a direct impact on the performance of the organization because it does not encourage creativity and innovation among the employees, and hence, employees do not perform as per expectations of the organization (Al Khajeh, 2018).

Transformational leadership focuses on setting a vision, being charismatic, developing employees and inspiring them to achieve better individual and organizational performance, thus, it's a strong predictor of organizational performance (Semedo, Coelho \&Ribeiro, 2016). In addition, it focuses on developing the followers and considering their needs particularly developing the followers overall value system, morals, skills and their motivation level as well as encourage them to look beyond their self-interest (Al Khajeh, 2018).

The followers of transformational leadership are associated with a self-defining and satisfying relationship with an individual or group. The idealized and behavioral charisma of the transformational leader motivates the followers to identify with the leader while the personalized relationship developed by the transformational leader cultivates an environment in which the followers feel happy and hence, their overall performance is improved ((Jyoti\&Bhau, 2015). Thus, transformational leadership has a significant impact on the performance of the organization (Al Khajeh, 2018). The transformational leader motivates the followers to identify with the leader while the personalized relationship developed by the transformational leader cultivates an environment in which the followers feel happy and hence, their overall performance is improved ((Jyoti\&Bhau, 2015). Thus, transformational leadership has a significant impact on the performance of the organization (Al Khajeh, 2018).

\section{RESEARCH METHODOLOGY}

The study employed the descriptive survey research design since the study was carried out in the Presbyterian Church of East Africa Nakuru East Presbytery. The PCEA church is governed by volunteers (elders) and Nakuru East Presbytery is one of the 56 Presbyteries of the Presbyterian Church. The Presbytery has 288 active elders and 462 Parish group leaders giving a total of 750 volunteer leaders which will constitute the study population.

In order to obtain the required sample size, the study employed the formula proposed by Nassiuma (2000) to calculate the required sample size from the target population of 728 , thus;

$$
n=\frac{N c^{2}}{c^{2}+(N-1) e^{2}}
$$

Where $\mathrm{n}=$ sample size, $\mathrm{N}=$ population size, $\mathrm{c}=$ coefficient of variation $(\leq 30 \%)$, and $\mathrm{e}=$ error margin $(\leq 3 \%)$. This formula enables the researcher to minimize the error and enhance stability of the estimates (Nassiuma, 2000). Substituting into the formula:

$$
n=\frac{750 *(0.3)^{2}}{(0.3)^{2}+(750-1) *(0.03)^{2}}=88.03 \approx 88
$$

The sample size was proportionally allocated across the categories of the respondent size using the Neyman allocation formula. The method helped to maximize survey precision given a fixed sample size. With Neyman allocation, the best sample size for stratum $h$ was:

$$
n_{h=}\left(\frac{N_{h}}{N}\right) n
$$

Where, $n_{h}$ is the sample size for stratum $h, n$ is the total sample size, $N_{h}$ is the population size for stratum $\mathrm{h}, \mathrm{N}$ is the total population. Hence, the study population was sampled as shown on Table 1 which was meant to make the sample as inclusive as possible.

Table1: Distribution of Respondents per Administrative Area

\begin{tabular}{|l|l|l|}
\hline \multicolumn{1}{|c|}{ Category } & \multicolumn{1}{c|}{ Population } & Sample size \\
\hline Elders & 288 & 33 \\
\hline Group Leaders & 462 & 55 \\
\hline Total & 750 & 88 \\
\hline
\end{tabular}


Influence of Volunteer Leaders' Competence on Church Performance: Evidence from the Presbyterian Church of East Africa Nakuru East Presbytery, Kenya

Table2: Distribution of Sampling Size into Strata

\begin{tabular}{|l|l|l|l|l|l|}
\hline & Parish & $\begin{array}{c}\text { Population of } \\
\text { Active Elders }\end{array}$ & Sample Size & $\begin{array}{c}\text { Population of } \\
\text { Parish Group Leaders }\end{array}$ & Sample Size \\
\hline 1. & Lanet & 51 & 6 & 42 & 5 \\
\hline 2. & Bahati & 22 & 3 & 42 & 5 \\
\hline 3. & Jerusalem & 25 & 3 & 42 & 5 \\
\hline 4. & Umoja & 26 & 3 & 42 & 5 \\
\hline 5. & St. Mary's & 15 & 2 & 42 & 5 \\
\hline 6. & Ngorika & 13 & 2 & 42 & 5 \\
\hline 7. & Tabuga & 28 & 3 & 42 & 5 \\
\hline 8. & Wendo & 23 & 3 & 42 & 5 \\
\hline 9. & Kirathimo & 26 & 3 & 42 & 5 \\
\hline 10. & Crater & 30 & 3 & 42 & 5 \\
\hline 11. & Wema & 29 & 3 & 42 & 5 \\
\hline TOTAL & $\mathbf{2 8 8}$ & $\mathbf{3 3}$ & $\mathbf{4 6 2}$ & $\mathbf{5 5}$ \\
\hline
\end{tabular}

Descriptive statistics was used to obtain frequencies and percentages. Inferential statistics in form of multiple linear regression analysis and Pearson correlation coefficient were used to test the association between volunteer leaders' competence and church performance. The results are presented in graphs and tables. The regression model was as follows:

$Y=\beta_{0}+\beta_{1} \chi_{1}+\beta_{2} \chi_{2}+\beta_{3} \chi_{3}+\beta_{4} \chi_{4}+\varepsilon$

Where:

$\mathrm{Y}=$ represents church performance

$\beta_{0}=$ represents constant

$\chi_{1}=$ represents leader's commitment

$\chi_{2}=$ represents emotional intelligence

$\chi_{3}=$ represents personal attributes

$\chi_{4}=$ represents leadership styles

$\varepsilon=$ is the error term (Assumed to be normally distributed).

\section{RESEARCH FINDINGS AND DISCUSSIONS}

\subsection{Correlation Matrix}

A correlation matrix is a table showing the correlation coefficients between sets of variables. Each cell in the table shows correlation between two variables. The correlation matrix allows detection of pairs that are highly correlated. This hence forms basis for further analysis and diagnostics. The study correlated the variables commitment, emotional intelligence, personal attributes, leadership styles and church performance.

Table3: Correlation Matrix

\begin{tabular}{|l|l|l|l|l|l|}
\hline & Commitment & $\begin{array}{c}\text { Emotional } \\
\text { Intelligence }\end{array}$ & $\begin{array}{c}\text { Personal } \\
\text { Attributes }\end{array}$ & $\begin{array}{c}\text { Leadership } \\
\text { Styles }\end{array}$ & $\begin{array}{c}\text { Church } \\
\text { Performance }\end{array}$ \\
\hline Commitment & 1 & & & & \\
\hline $\begin{array}{l}\text { Emotional } \\
\text { Intelligence }\end{array}$ & 0.452 & 1 & & & \\
\hline $\begin{array}{l}\text { Personal } \\
\text { Attributes }\end{array}$ & 0.57 & 0.529 & 1 & 1 & \\
\hline $\begin{array}{l}\text { Leadership } \\
\text { Styles }\end{array}$ & 0.705 & 0.455 & 0.657 & 1 & \\
\hline $\begin{array}{l}\text { Church } \\
\text { Performance }\end{array}$ & 0.417 & 0.303 & 0.44 & 0.452 & 1 \\
\hline
\end{tabular}

The study found that there was moderate positive correlation between commitment and emotional intelligence $(\mathrm{r}=0.452)$. There was also a positive moderate correlation between commitment and personal attributes $(\mathrm{r}=0.57)$. Personal attributes were also positively correlated with emotional intelligence $(\mathrm{r}=0.529)$. This study also found a positive high correlation between leadership styles and 
Influence of Volunteer Leaders' Competence on Church Performance: Evidence from the Presbyterian Church of East Africa Nakuru East Presbytery, Kenya

commitment $(\mathrm{r}=0705)$, positive moderate correlation between leadership styles and emotional intelligence $(\mathrm{r}=0.455)$ and also a positive high correlation between leadership styles and personal attributes $(\mathrm{r}=0.452)$. These findings were presented in Table 4.10.

The correlation matrix revealed correlation between the independent variables of the study and hence informed that there was need for further analysis to diagnose for multicollinearity in regression analysis. The table revealed that all the independent variables were correlated to the dependent variable church performance.

\subsection{Multiple Regression}

Multiple regression is an extension of simple regression. It is used to predict the value of a dependent variable based on the value of two or more independent variables. It hence helps understand how the depend variable changes as we change the independent variables altogether. This study ran a multiple regression with independent variables commitment, emotional intelligence, personal attributes and leadership styles and the dependent variable church performance.

Table4: Model Summary

\begin{tabular}{|l|l|l|l|l|l|}
\hline Model & \multicolumn{1}{|l|}{ R } & R Square & Adjusted R Square & Std. Error of the Estimate & Durbin-Watson \\
\hline 1 & $0.502 \mathrm{a}$ & 0.252 & 0.218 & 3.3244 & 1.755 \\
\hline \multicolumn{2}{|l|}{ a Predictors: (Constant), Leadership Styles, Emotional Intelligence, Personal Attributes, Commitment } \\
\hline \multicolumn{2}{|l}{ b Dependent Variable: Church Performance } \\
\hline
\end{tabular}

The study found the model explained $25.2 \%$ variation $\left(\mathrm{R}^{\wedge} 2=0.252\right)$ in church performance. The study also diagnosed autocorrelation in the dependent variable using Durbin Watson test. A value of 1.755 was obtained indicating that there no autocorrelation in the dependent variable.

Table5: $A N O V A$

\begin{tabular}{|l|l|l|l|l|l|l|}
\hline & Model & Sum of Squares & df & Mean Square & F & Sig. \\
\hline 1 & Regression & 324.466 & 4 & 81.117 & 7.34 & $.000 \mathrm{~b}$ \\
\hline & Residual & 961.49 & 87 & 11.052 & & \\
\hline & Total & 1285.957 & 91 & & & \\
\hline
\end{tabular}

ANOVA tests was used to assess whether the model was a good fit of the data. The test indicated that the model was significantly $(\mathrm{F}=7.34$, Sig. $<0.05)$ different from a null model confirming that indeed the model was a good fit of the data.

Table6: Coefficients

\begin{tabular}{|l|l|l|l|l|l|l|}
\hline & $\begin{array}{c}\text { Unstandardized } \\
\text { Coefficients }\end{array}$ & $\begin{array}{c}\text { Standardized } \\
\text { Coefficients }\end{array}$ & \multicolumn{1}{|c|}{ t } & \multicolumn{2}{|c|}{ Sig. } & \multicolumn{2}{|c|}{ Collinearity Statistics } \\
\hline & $\mathrm{B}$ & Beta & & & Tolerance & VIF \\
\hline (Constant) & 6.487 & & 1.532 & 0.129 & & \\
\hline Commitment & 0.187 & 0.141 & 1.044 & 0.299 & 0.472 & 2.119 \\
\hline $\begin{array}{l}\text { Emotional } \\
\text { Intelligence }\end{array}$ & 0.059 & 0.038 & 0.338 & 0.736 & 0.684 & 1.462 \\
\hline $\begin{array}{l}\text { Personal } \\
\text { Attributes }\end{array}$ & 0.252 & 0.21 & 1.59 & 0.116 & 0.492 & 2.033 \\
\hline $\begin{array}{l}\text { Leadership } \\
\text { Styles }\end{array}$ & 0.225 & 0.198 & 1.359 & 0.178 & 0.405 & 2.468 \\
\hline a Dependent Variable: Church Performance & & & & \\
\hline
\end{tabular}

This study also found that commitment had no significant $(\beta=0.187$, Sig. $>0.05)$ influence on church performance while controlling for emotional intelligence, personal attributes and leadership styles. Similarly, emotional intelligence had no significant $(\beta=0.059$, Sig. $>0.05)$ influence on church performance while controlling for commitment, personal attributes and leadership styles. The study also found that personal attributes had no significant $(\beta=0.252$, Sig. $>0.05)$ on church performance while controlling for commitment, emotional intelligence and leadership styles. There was also no significant influence of leadership styles on church performance. The study also tested for multicollinearity on the independent variables using Variance Inflation Factor (VIF). None of the variables had a value greater than 10 and hence the study concluded that there was no significant collinearity in the independent variables. The $\mathrm{R}$ resulting regression model is as shown here. Church 
performance $=6.487+0.187 *$ Commitment $+0.059 *$ Emotional Intelligence $+0.252 *$ Personal Attributes $+0.225^{*}$ Leadership Styles. However, the study found that the independent variables could not jointly predict the church performance hence the model was not adopted.

\section{Conclusion of The Study}

The study concluded that volunteer leaders' commitment, emotional intelligence, personal attributes and leadership styles contributed to a large extent to the performance of P.C.E.A Nakuru East Presbytery. Majority of the volunteer leaders found that volunteer leaders in the Presbytery would leave and volunteer in another organization when given an opportunity. This indicates that the volunteer leaders have low commitment to their roles in the church and are thus not focused on achieving the goals and visions of the church.

The research also concludes that volunteer leaders in the church are able to manage their emotions effectively. Majority of them indicated that they are considerate to the feelings of others and are also instrumental in conflict management. Additionally, the personal attributes of volunteer leaders are an important aspect in enhancing church performance. From the results obtained in this research, teaching and mentoring others is a significant attribute that the majority of volunteer leaders possess.

The volunteer leaders have leadership styles that are effective and blend well with the nature of the organization they operate. Majority of the volunteer leaders consult widely before making decisions and often set standards for performance of tasks as well as set an example to be emulated by others, a leadership style that makes them more effective in their roles.

\section{RECOMMENDATIONS}

\section{Recommendation for Practice and Policy}

On the basis of the findings of this study, the following recommendations are important as far as establishing the influence of volunteer leaders' competence on church performance. First, the church should acknowledge the great role volunteer leaders play, appreciate them, provide a conducive working environment that can help them execute their roles effectively and involve them more in decision making as a way of motivating them since a majority of them said they would leave and volunteer in another organization given an opportunity. Secondly, the church should invest more in training their volunteer leaders since some were not aware that leaders are trained after induction and also a majority agreed that training has made them more effective in their roles. Thirdly, since experienced volunteer leaders' have the ability to navigate most challenges and also perform their duties more effectively, the church should create a conducive environment for them to share their experience as well as encourage them to train and mentor others.

\section{Recommendation for Further Research}

A study can be conducted to determine the influence of the various aspects of volunteer leaders' competence on church performance. Further research can be undertaken on how volunteer leaders' competence may impact the various aspects of church performance (membership growth, church attendance, ability to meet financial obligations and completion of church projects). Another study can be conducted to examine the strategies that can be taken to enhance volunteer leaders' competence to increase church performance.

\section{REFERENCES}

[1] Adenike, A. (2011). Organizational climate as a predictor of employee job satisfaction: Evidence from Covenant University. Abuja, NG: Covenant University.

[2] Afari-Asiedu, S., Asante, K. P., Senah, K., Abdulai, M. A., Afranie, S., Mahama, E., \&Owusu-Agyei, S. (2018). Volunteering for Health Services in the Middle Part of Ghana: In Whose Interest? International journal of health policy and management, 7(9), 836.

[3] Ajibade, O. S., \&Ayinla, K. N. (2014). Investigating the effect of training on employees' commitment: An empirical study of a discount house in Nigeria. Megatrend revija, 11(3), 7-18.

[4] Al Khajeh, E. H. (2018). Impact of Leadership Styles on Organizational Performance.

[5] Asilaza, N. (2016). The Effect of Emotional Intelligence on Employee Performance in the Private Sector: A Case of Kinyara Sugar Limited (Doctoral dissertation).

[6] Australia, V. (2015). Key facts and statistics about volunteering in Australia. Retrieved May, 10, 2016. 
Influence of Volunteer Leaders' Competence on Church Performance: Evidence from the Presbyterian Church of East Africa Nakuru East Presbytery, Kenya

[7] Balduck, A. L., Van Rossem, A., \&Buelens, M. (2010). Identifying competencies of volunteer board members of community sports clubs. Nonprofit and Voluntary Sector Quarterly, 39(2), 213-235.

[8] Bell, J., Masoka, J., \& Zimmerman, S. (2010). Nonprofit sustainability: Making strategic decisions for financial viability. San Francisco, CA: Jossey-Bass.

[9] Bettin, P.J., \& Kennedy, J.K. (2010). Leadership experience and leader performance: Some empirical support at last. The Leadership Quarterly, 1(4), 219-228.

[10] Blau, P. M. (1964). Exchange and power in social life. New Brunswick.

[11] Blau, P. M. (1994). The organization of academic work. Transaction Publishers.

[12] Brunette, C. A. (2011). The functional approach to volunteerism in organizational volunteers (Doctoral dissertation, University of Missouri--Columbia).

[13] Bukirwa, S., \&Kising'u, M. T. (2017). Influence of competitive strategies on organizational performance of hotels in Kenya (a survey of hotels in Mombasa County). Strategic Journal of Business \& Change Management, 4(2), 138-158.

[14] Chavannes, E. (1901). Le dieu du sol dansl'ancienne religion chinoise. Revue de l'histoire des religions, 125-146.

[15] Coyle-Shapiro, J. A. M., Morrow, P. C., \& Kessler, I. (2006). Serving two organizations: Exploring the employment relationship of contracted employees. Human Resource Management: Published in Cooperation with the School of Business Administration, the University of Michigan and in alliance with the Society of Human Resources Management, 45(4), 561-583.

[16] Dinh, J. E., Lord, R. G., Gardner, W. L., Meuser, J. D., Liden, R. C., \& Hu, J. (2014). Leadership theory and research in the new millennium: Current theoretical trends and changing perspectives. The Leadership Quarterly, 25(1), 36-62.

[17] Donahue, B., \& Robinson, R. G. (2009). The seven deadly sins of small group ministry. Zondervan.

[18] Elnaga, A., \& Imran, A. (2013). The effect of training on employee performance. European Journal of Business and Management, 5(4), 137-147.

[19] Ghoneim, N., \&Baradei, L. (2013). The impact of strategic planning on Egyptian non-profits' performance: an assessment using the balanced scorecard. Journal of US- China Public Administration, 10(1), 57-76.

[20] Goleman, D. (2011). Leadership: The power of emotional intelligence. Northampton: More than Sound.

[21] Gorgens, M., \&Kusek, J. Z. (2010). Making monitoring and evaluation systems work: a capacity development tool kit. The World Bank.

[22] Humphrey, R. H. (2012). How do leaders use emotional labor? Journal of Organizational Behavior, 33(5), 740-744.

[23] Hurduzeu, R. E. (2015). The impact of leadership on organizational performance. SEA-Practical Application of Science, 3(07), 289-293.

[24] Jyoti, J., \&Bhau, S. (2015). Impact of transformational leadership on job performance: Mediating role of leadermember exchange and relational identification. SAGE Open, 5(4), 2158244015612518.

[25] Kabetu, D. G., \&Iravo, M. A. (2018). Influence of strategic leadership on performance of international humanitarian organizations in Kenya. International Academic Journal of Innovation, Leadership and Entrepreneurship, 2(2), 113-135.

[26] Kelloway, E. K., Turner, N., Barling, J., \&Loughlin, C. (2012). Transformational leadership and employee psychological well-being: The mediating role of employee trust in leadership. Work \& Stress, 26(1), 39-55.

[27] Khan, S. I., Mahmood, A., Kanwal, S., \&Latif, Y. (2015). How perceived supervisor support effects workplace deviance? Mediating role of perceived organizational support. Pakistan Journal of Commerce and Social Sciences (PJCSS), 9(3), 940-967.

[28] Perold, H., Graham, L. A., Mavungu, E. M., Cronin, K., Muchemwa, L., \& Lough, B. J. (2013). The colonial legacy of international voluntary service. Community Development Journal, 48(2), 179-196.

[29] Prasetya, A. (2018). Analysis of factors that influence employee performance (Study on Permanent Employees in Operational Section of PT WI Cycle Indonesia-Surabaya). Profit (journal of administrative business), 12(1), 1-12.

[30] Presbyterian Church of East Africa (1998). The Practice and Procedure Manual. Nairobi: Publishing Solutions.

[31] Rodell, J. B., Breitsohl, H., Schroder, M., \& Keating, D. J. (2016). Employee volunteering: A review and framework for future research. Journal of management, 42(1), 55-84.

[32] Royster Sr, M. E. (2016). Pastoral Leadership Behavior, Church Growth and Membership Longevity: A Multiple Case Study. North central University.

[33] Sajjadi, A., Karimkhani, M., \&Mehrpour, M. (2014). New emerging leadership theories and styles. Technical Journal of Engineering and Applied Sciences, 4(3), 180-188. 
Influence of Volunteer Leaders' Competence on Church Performance: Evidence from the Presbyterian Church of East Africa Nakuru East Presbytery, Kenya

[34] Saunders, M., Lewis, P., \&Thornhill, A. (2007). Research methods. Business Students 4th edition Pearson Education Limited, England.

[35] Scott, B. (2007). What impact does training have on employee commitment and employee turnover? Kingston: University of Rhode Island.

[36] Semedo, A. S. D., Coelho, A. F. M., \&Ribeiro, N. M. P. (2016). Effects of authentic leadership, affective commitment and job resourcefulness on employees' creativity and individual performance. Leadership \& Organization Development Journal, 37(8), 1038-1055.

[37] Smith, M. E. (2017). The Relationship between Leadership Style and Volunteer Intention to Stay.

[38] Smith, S. R., Hamon, R. R., Ingoldsby, B. B., \& Miller, J. E. (2012). Exploring family theories. New York, NY: Oxford University Press.

[39] Spendlove, M. (2007). Competencies for effective leadership in higher education. International Journal of Educational Management, 21(5), 407-417.

[40] Thegu, Mutahi (2018). My Presbyterian Handbook. Nairobi: PCEA Jitegemea Press.

[41] Thomas, V. B., Selvadurai, S., Er, A. C., Lyndon, N., \&Moorthy, R. (2011). Factors Influencing Commitment of Volunteers' in Neighborhood Watch Organization. Journal of Social Sciences, 7(4), 569.

[42] Uchenwamgbe, B. B. P. (2013). Effects of leadership style on organizational performance in small and medium scale enterprises (SMEs) in Nigeria. European Journal of Business and Management, 5(23), 53-73.

[43] United States Department of Labor, Bureau of Labor Statistics. (2014). Volunteering in the United States2014. (News Release USDL-14-0314).

[44] Vecina, M. L., Chacón, F., Marzana, D., \& Marta, E. (2013). Volunteer engagement and organizational commitment in nonprofit organizations: What makes volunteers remain within organizations and feel happy? Journal of Community Psychology, 41(3), 291-302.

[45] Vick, J. P. (2011). Servant leadership, volunteer administration, and the local church: the relationship between servant leader characteristics and volunteer administration skills among church leaders (Doctoral dissertation, Temple University).

[46] Virkus, S. (2009). Leadership Attributes: Trait Approach. Tallinn University.

[47] Wang, C. L., Indridason, T., \& Saunders, M. N. (2010). Affective and continuance commitment in public private partnership. Employee Relations, 32(4), 396-417.

[48] Wilson, J. (2012). Volunteerism research: A review essay. Nonprofit and Voluntary Sector Quarterly, 41 (2), 176-212.

[49] Yin, R. K. (2017). Case study research and applications: Design and methods. Sage publications.

[50] Zaccaro, S. J. (2007). Trait-based perspectives of leadership. American psychologist, 62(1), 6.

\section{AUTHORS' BIOGRAPHY}

MS. Pauline Kanuthu Mwaura is a candidate of Master of Science in Organisational development (Human resource). She is also a dedicated Reverend In the Presbyterian Church Of East Africa, Kenya.

Dr. Njenga Gitahi Lectures and specializes with Strategic Management aspects as a discipline and has strong inclination and knowledge on Research Methodologies and Statistical Analysis. (Quantitative and Qualitative).

Dr. Maina Waiganjo is a Senior Lecturer (Kabarak University) and Specializes in Human Resource. $\mathrm{He}$ is well versed with multidisciplinary academic aspects with over fifteen years of experience. His strong areas also include research, psychology and Theology.

Citation: Dr. Njenga Gitahi, et.al. “Influence of Volunteer Leaders' Competence on Church Performance: Evidence from the Presbyterian Church of East Africa Nakuru East Presbytery, Kenya" International Journal of Managerial Studies and Research (IJMSR), vol 7, no. 11, 2019, pp. 52-66. doi: http://dx.doi.org/10.20431/23 49-0349.0711006.

Copyright: (C) 2019 Authors. This is an open-access article distributed under the terms of the Creative Commons Attribution License, which permits unrestricted use, distribution, and reproduction in any medium, provided the original author and source are credited. 